Article

\title{
Coarse Woody Debris as a Land Reclamation Amendment at an Oil Sands Mining Operation in Boreal Alberta, Canada
}

\author{
Bradley D. Pinno ${ }^{1, *(\mathbb{D})}$ and Sanatan Das Gupta ${ }^{2}$ \\ 1 University of Alberta, Department of Renewable Resources, Edmonton, AB T6G 2E3, Canada \\ 2 Natural Resources Canada, Canadian Forest Service, Edmonton, AB T6H 3S5, Canada; \\ sanatan.dasgupta@canada.ca \\ * Correspondence: bpinno@ualberta.ca; Tel.: +1-780-492-1280
}

Received: 11 April 2018; Accepted: 16 May 2018; Published: 19 May 2018

\begin{abstract}
Coarse woody debris (CWD) is an important component of natural forests and is now being used in reclaiming oil sands land to control erosion, enhance diversity, and function as longer term storage of organic matter. However, the impact of woody debris on reclaimed ecosystems may vary depending on the amount applied and the soil it is applied to. We studied the impact on the plant community (including tree regeneration and understory plants) and soil properties of four levels of CWD cover (None, Low, Moderate, High) on two reclamation soils (forest floor-mineral mix and peat-mineral mix) and natural post-fire soils. Significant differences were observed among soil types in terms of the plant community and soil properties but fewer differences were attributable to CWD. However, overall native plant species' diversity and abundance decreased with High CWD while cover of non-native species on the reclaimed soils greatly decreased with Low CWD. Natural seedling regeneration density of trembling aspen was unaffected by CWD on both reclamation soil types. The soil nutrient supply rates and soil moisture were significantly different among soil types but there were no differences among debris treatments while soil temperature decreased with CWD. Overall, a Low (up to $30 \%$ ground cover) woody debris application appears to be optimal for maintaining native plant species diversity and abundance while controlling undesirable plant species.
\end{abstract}

Keywords: oil sands; land reclamation; forest restoration; peat-mineral mix; forest floor-mineral mix; plant community; trembling aspen

\section{Introduction}

Coarse woody debris (CWD) plays many critical roles in the functioning of forest ecosystems, which varies from understory plant establishment to nutrient cycling. In natural forests, CWD is the result of natural ecosystem events ranging from single tree death to large scale events such as fire where all or most of the trees on a site are killed. In anthropogenic ecosystems such as mine land reclamation sites, CWD presence is the result of purposeful placement of CWD as a reclamation treatment. This dead wood has been shown to influence the plant community indirectly through the provisioning of suitable microsites for seedling establishment $[1,2]$ as well as directly as a seed source for canopy seed-banking tree species such as jack pine and black spruce [3]. In terms of soil nutrients, CWD influences soil $\mathrm{N}$ and $\mathrm{P}$ cycles [4] through changes in mineralization and immobilization rates of these nutrients in which CWD is often associated with decreased inorganic N. This indicates net immobilization $[2,5]$. These nutrient cycling processes, in turn, are largely controlled through the microbial community, which has also been shown to be influenced by CWD [6]. Other impacts of CWD in forests include a long-term carbon and nutrient store $[7,8]$, a control on greenhouse gas emissions 
from soil [9], and habitat for many different species of both vertebrate and invertebrate wildlife [10,11]. Given this important ecological role of CWD in forests, there is greater interest in expanding the use of CWD as a site amendment in land reclamation projects following oil sands mining.

Oil sands mining results in the complete removal of forest ecosystems to access the oil sands ore followed by ecosystem reconstruction during land reclamation [12]. This reclamation process involves landform construction of overburden or tailings dumps, which are subsequently capped with cover soils rich in organic matter of either upland or the wetland origin. During the salvage process, timber is harvested with merchantable material sent to local mills for processing. However, smaller-sized trees and undesirable species may be available for use in reclamation activities as a surface amendment to be applied on top of the cover soils. This application of CWD has been used as an erosion control measure in oil sands reclamation but there may be other ecological benefits related to the plant community and soil properties, which deserve further study. Given the large size of the mineable oil sands region (4800 $\mathrm{km}^{2}$ ) within the boreal forest of Alberta, Canada, there will be large areas that require reclamation in the coming decades. Therefore, practices such as CWD applications need to be tested for efficacy in helping to ensure successful reclamation outcomes.

Previous studies examining CWD in oil sands mine reclamation settings have provided an initial indication of some positive impacts of CWD applications, which is similar to what has been seen in natural forests. These finding include increased plant cover [2], changes in soil microbial communities and respiration [6,9], and changes in soil chemical and physical properties $[2,13]$ due to CWD application. However, prior to widespread adoption of the CWD application as a viable land reclamation tool with positive ecological outcomes, there are important questions related to application amounts and differential effects among reclamation soils, which remain to be answered. The goal of this research study was to determine the overall impacts of CWD on vegetation communities (including both understory plant and trees) and soil properties (nutrient availability and physical properties) in different reclamation soils and in natural benchmark (fire origin) stands. The general hypothesis for this work is that the ecological impact of CWD on vegetation and soil properties will vary among soil types with CWD amount and with the greatest benefits of CWD coming on the reclamation sites. Operationally, we also wanted to refine these impacts based on the amount of CWD present on the site to help inform land reclamation practitioners who are applying, or would like to apply, CWD to their sites.

\section{Methods}

The study area was located approximately $75 \mathrm{~km}$ northwest of Fort McMurray, $\mathrm{AB}\left(57^{\circ} 21^{\prime} \mathrm{N}\right.$, $111^{\circ} 49^{\prime} \mathrm{W}$ ), on a six-year-old reclaimed landform constructed in 2011 within an oil sands mine and in six-year-old nearby natural forests, which were burnt by the Richardson Fire in 2011. The modal forest type in the region is trembling aspen (Populus tremuloides) and white spruce (Picea glauca) mixed woods [14]. This is the forest type of the burnt areas as well as the desired future forest for the reclaimed area. The climate (Fort McMurray station climate values from Environment Canada) is characterized by a mean July temperature of $17.1^{\circ} \mathrm{C}$ and January temperature of $-17.4^{\circ} \mathrm{C}$ with an annual precipitation of $419 \mathrm{~mm}$. The summer of 2016 during which the measurements for this study were taken had a May to September growing season with precipitation of $248 \mathrm{~mm}$, which is $80 \%$ of normal precipitation for this time and it indicates that 2016 was slightly drier than the normal growing season.

The reclaimed site is an 88.6 ha overburden dump constructed in 2011 as an operational reclamation site featuring two different surface reclamation soil types, peat-mineral mix (PMM), and forest floor-mineral mix (FFMM) with areas of CWD addition where this study was focused. The surface reclamation soils were both salvaged in the winter of 2010-2011 and then directly placed on the reclamation site at a depth of approximately $0.5 \mathrm{~m}$ over $1.5 \mathrm{~m}$ of suitable (non-saline) subsoil resulting in a $2.0 \mathrm{~m}$ cap above the saline-sodic overburden. The PMM is derived from lowland bog and fen deposits, and the underlying mineral soil. It is a varying mixture of peat and mineral soil at 
an overall ratio of approximately 60:40. This reclamation soil type has high organic matter and an associated high water holding capacity, which results in high natural tree seeding establishment [15] but lower native plant establishment due to its lowland origin [16]. The FFMM is derived from upland forest sites and consists of the forest floor organic layer and the underlying A and B horizons salvaged to a depth of approximately $0.3 \mathrm{~m}$. This reclamation soil has a high native plant establishment as a biological legacy of the previous forest soil propagule bank [16,17] and a nutrient regime that is more similar to natural forest soils than PMM [18]. The reclamation site was aerially fertilized with $100 \mathrm{~kg} \mathrm{~N} \mathrm{ha}^{-1}$ (equivalent N: 29.9-9.1-9.1-9.1 NPKS) and applied in both 2011 and 2012, which resulted in a total $\mathrm{N}$ application of $200 \mathrm{~kg} \mathrm{ha}^{-1}$. The site was seeded with annual barley (Hordeum vulgare) to control potential erosion and then planted with 2000 white spruce seedlings per ha in 2011.

The CWD application consisted of tops, branches, and small stems of coniferous trees (mainly black spruce-Picea mariana) spread across a portion of the reclamation site. The result of this application approach is that most of the CWD is in small fragments and pieces of wood to depths of up to $0.2 \mathrm{~m}$ rather than as individual logs, which was applied in other treatments. Therefore, we chose to characterize the CWD application by percent coverage rather than by volume of material applied. The CWD was also unevenly applied across the site so this heterogeneity was utilized in our study design to examine the impacts of varying coverage of CWD on ecosystem development (see Figure 1). The CWD application was characterized at the plot level as None ( $0 \%$ CWD), Low ( $1 \%-30 \%)$, Moderate $(31 \%-70 \%)$, and High $(71 \%-100 \%)$. This same classification system was used for the natural fire reference sites but the quality of the CWD in these sites was quite different since it consisted of mainly whole, burnt deciduous boles, which have subsequently fallen down.

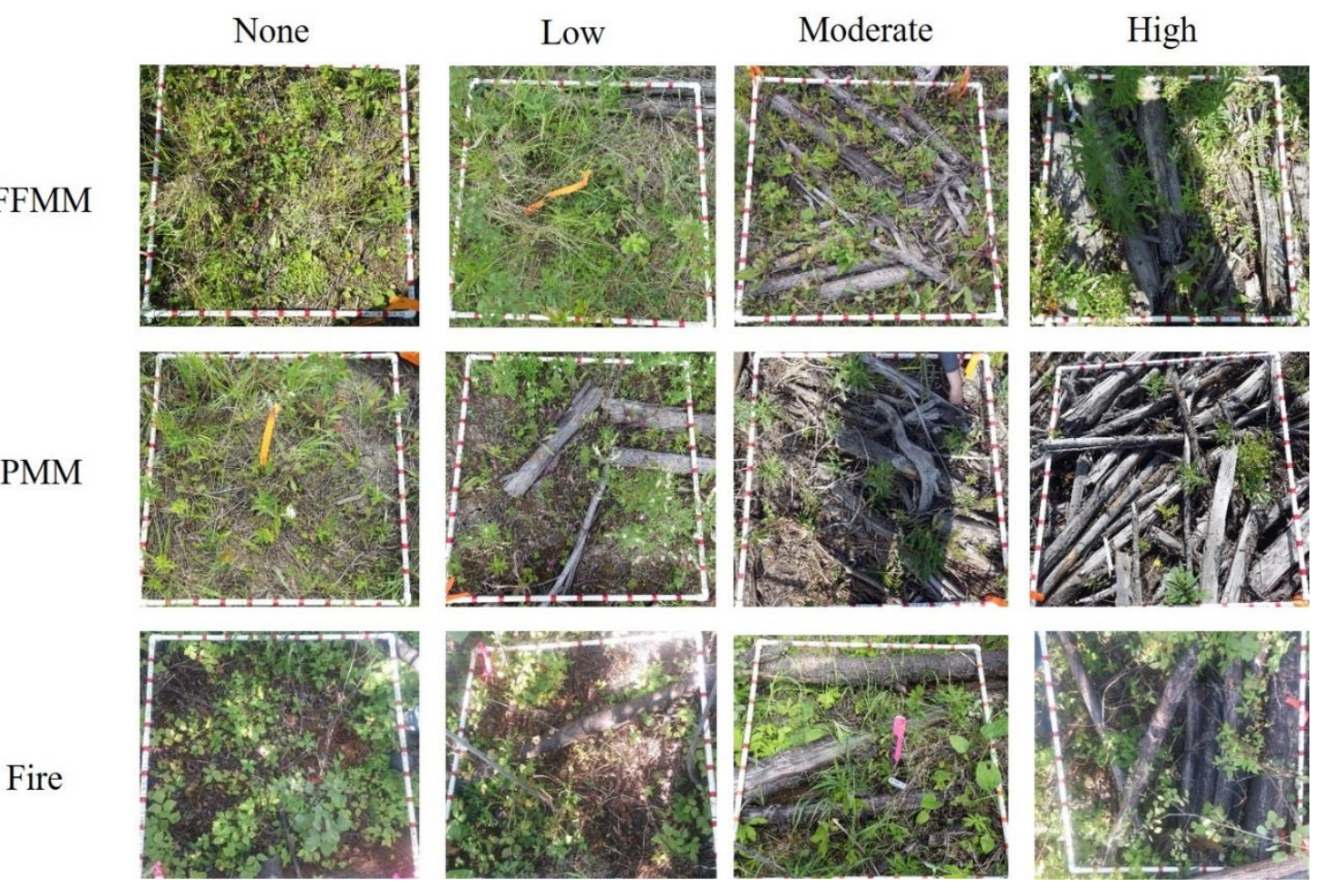

Figure 1. Visual representation of CWD levels in each soil type. The pictures are intended to highlight the CWD levels and not the plant community, which may not be representative of that treatment class. The quadrat frame in all pictures is $1 \times 1 \mathrm{~m}$. All photos by S. Das Gupta. FFMM = Forest floor - mineral mix, PMM = Peat - mineral mix. None is $0 \%$ CWD, Low is $1 \%-30 \%$ CWD, Moderate is $31 \%-70 \%$ CWD, and High is $71 \%-100 \%$ CWD. 
The experimental design for this study consists of three site types (PMM and FFMM from the reclamation site and Fire as the natural benchmark comparison) and four levels of CWD (None, Low, Moderate, High) with nine randomly located sampling blocks in PMM, 11 in FFMM, and 10 in Fire. The original plan was to have 10 blocks in each site type but one of the blocks was misallocated, which resulted in the slightly uneven sampling design. At each sampling block, the closest representative location from each of the four CWD classes of at least $50 \mathrm{~m}^{2}$ in size of relatively consistent CWD was selected and a sampling plot was established. At each sampling plot, a series of plant community, tree, and soil measures were taken during the summer of 2016 in the sixth post-disturbance growing season for all the sites.

To characterize the plant community, a 1- $\mathrm{m}^{2}$ survey quadrant was used to determine richness (at the species level) and abundance (percent cover at the functional group level). Functional groups include graminoids, forbs, woody plants, bryophytes, native species, and non-native species recorded to the nearest percent of coverage. Substrate coverage was also recorded and included CWD, bare soil, water, and rock recorded to the nearest percent.

Tree regeneration metrics focused on naturally establishing deciduous trees in which the most common was trembling aspen (over 95\% of regenerating stems recorded). At the Fire site, the aspen regeneration was asexually from root suckers while, on the PMM and FFMM sites, the aspen regeneration was from natural seedling establishment [19]. Conifer regeneration abundance was not included in the regeneration comparison since the reclamation site was planted at a density of approximately 2000 stems per hectare with white spruce while the Fire site lacked conifer regeneration. Regeneration was counted by species in $1.78 \mathrm{~m}$ radius plots and the basal diameter of each stem was recorded. For some Fire plots with a high regeneration density, a $1 \mathrm{~m}$ radius was used to assess tree regeneration, so per ha values are given. Tree growth and productivity was assessed using the average basal diameter by species for each plot.

Soil samples were collected from $0 \mathrm{~cm}$ to $15 \mathrm{~cm}$ depth at each plot and then air dried before determining $\mathrm{pH}$ and electrical conductivity (EC) in water. Volumetric water content (VWC\%) and soil temperature $\left({ }^{\circ} \mathrm{C}\right.$ ) were recorded monthly (June, July, August) from each plot by using a time-domain reflectometer (Field Scout TDR 300 Soil Moisture Meter; Spectrum Technologies Inc., Aurora, IL, USA) and a standard field thermometer, respectively. Soil nutrient supply rates were assessed using Plant Root Simulator (PRS ${ }^{\mathrm{TM}}$ ) probes (Western Ag Innovation, Saskatoon, SK, Canada). Anion and cation probes were installed for 55 days during the growing season in five randomly selected blocks on each site with four pairs of probes in each CWD class. After removal, probes were cleaned with deionized water and kept cool until extraction and laboratory analysis was completed at Western Ag Innovations. $\mathrm{NO}_{3}-\mathrm{N}$ and $\mathrm{NH}_{4}-\mathrm{N}$ were determined colorimetrically using an automated flow injection analysis system while all other ions were determined using inductively-coupled plasma spectrometry. For this study, we focused on macronutrient supply rates including total $\mathrm{N}\left(\mathrm{NO}_{3}+\mathrm{NH}_{4}\right), \mathrm{P}, \mathrm{K}, \mathrm{S}, \mathrm{Ca}$, and $\mathrm{Mg}$. Soil and site properties for the No CWD plots are given in Table 1.

Table 1. Soil and site properties of the control plots (CWD = None). Values have a mean and standard error. $\mathrm{FFMM}=$ forest floor - mineral $\mathrm{mix}, \mathrm{PMM}=$ peat - mineral $\mathrm{mix}, \mathrm{VWC}=$ volumetric water content.

\begin{tabular}{|c|c|c|c|c|c|c|}
\hline & $\mathrm{pH}$ & $\begin{array}{l}\text { VWC } \\
(\%)\end{array}$ & $\begin{array}{c}\text { Plant Cover } \\
(\%)\end{array}$ & $\begin{array}{l}\text { Tree Density } \\
\left(\text { Stems ha }^{-1}\right)\end{array}$ & $\begin{array}{c}\text { P } \\
\left(\mu \mathrm{g} 10 \mathrm{~cm}^{-2} 55 \text { Days }^{-1}\right)\end{array}$ & $\mathrm{K}$ \\
\hline FFMM & $\begin{array}{c}6.77 \\
(0.21)\end{array}$ & $\begin{array}{l}28.4 \\
(3.1)\end{array}$ & $\begin{array}{l}61.5 \\
(5.0)\end{array}$ & $\begin{array}{c}9,180 \\
(2,920)\end{array}$ & $\begin{array}{c}4.09 \\
(2.67)\end{array}$ & $\begin{array}{c}59 \\
(14.6)\end{array}$ \\
\hline PMM & $\begin{array}{c}6.41 \\
(0.37)\end{array}$ & $\begin{array}{l}41.9 \\
(3.3)\end{array}$ & $\begin{array}{c}44.1 \\
(10.3)\end{array}$ & $\begin{array}{l}12,770 \\
(4,700)\end{array}$ & $\begin{array}{c}1.80 \\
(0.58)\end{array}$ & $\begin{array}{l}36.1 \\
(4.5)\end{array}$ \\
\hline Fire & $\begin{array}{c}6.02 \\
(0.18)\end{array}$ & $\begin{array}{l}13.0 \\
(1.7)\end{array}$ & $\begin{array}{l}70.5 \\
(6.7)\end{array}$ & $\begin{array}{l}35,900 \\
(5,220)\end{array}$ & $\begin{array}{l}21.01 \\
(3.42)\end{array}$ & $\begin{array}{l}379.1 \\
(45.3)\end{array}$ \\
\hline
\end{tabular}


Statistical analyses consisted of two-way ANOVAs (Soil $\times$ CWD) followed by Tukey's HSD post-hoc tests where appropriate. Response variables consisted of a plant community, tree regeneration density, basal diameter, and soil chemical and physical properties. All statistics were completed using SYSTAT 13.0 (SYSTAT Software, San Jose, CA, USA).

\section{Results}

Overall, native species' richness was similar between Fire and FFMM sites ( $p=0.474)$, but significantly lower on PMM $(p<0.001)$ (see Figure 2a). Native species' richness was reduced at High CWD compared to all other CWD levels $(p<0.001)$, which were not significantly different from each other $(p>0.806)$. The coverage of native species was also significantly different among all soil types $(p<0.001)$ with Fire $>$ FFMM $>$ PMM (see Figure 2b). For CWD levels, high CWD had significantly lower coverage than the other CWD levels $(p<0.001)$. There were no non-native species present in any of the Fire plots but, within the reclaimed plots, coverage of non-native species was similar between PMM and FFMM ( $p=0.912)$. On PMM and FFMM reclaimed soils, non-native coverage was significantly greater $(p<0.001)$ with no CWD compared to all other CWD levels (see Figure 2c). The most common native and non-native species in each of the soil types are given in Table 2.

Table 2. Most common native and non-native species in each of the soil types. Note: species are listed alphabetically and not by order of importance.

\begin{tabular}{ccc}
\hline & Native Species & Non-Native Species \\
\hline FFMM & Agropyron trachycaulon & Melilotus alba \\
& Calamagrostis canadensis & Plantago major \\
& Chamerion angustifolium & Sonchus arvensis \\
& Equisetum arvense & Taraxacum officianale \\
& Fragaria virginiana & \\
& Rubus ideaus & \\
\hline PMM & Chamerion angustifolium & Chenopodium album \\
& Epilobium ciliatum & Crepis tectorum \\
& Equisetum arvense & Sonchus arvensis \\
& Fire & Taraxacum officianale \\
\hline & Calamagrostis canadensis & None present \\
& Cornus canadensis & \\
Galium boreale & \\
& Petasites palmatus & \\
& Viburnum edule &
\end{tabular}

Coverage of bare ground was significantly greater $(p<0.001$, data not shown) on PMM (average $=56 \%$ on No CWD plots) compared to FFMM and Fire plots (average $=20 \%$ ). Among CWD levels, no CWD plots had significantly more bare ground than plots with CWD $(p<0.001)$ but with high CWD, all soil types had similar bare ground coverage of $5 \%$ (soil $\times$ CWD interaction $p=0.002$ ).

Natural trembling aspen regeneration density was significantly greater on Fire when compared to the reclaimed sites $(p<0.001)$ while, on the reclaimed sites, regeneration density was similar between PMM and FFMM ( $p=0.233$ ) (see Figure 3a). CWD levels did not have an impact on aspen regeneration on either PMM or FFMM but regeneration was reduced significantly on high CWD plots in the Fire sites (soil $\times$ CWD interaction $p=0.017$ ). 

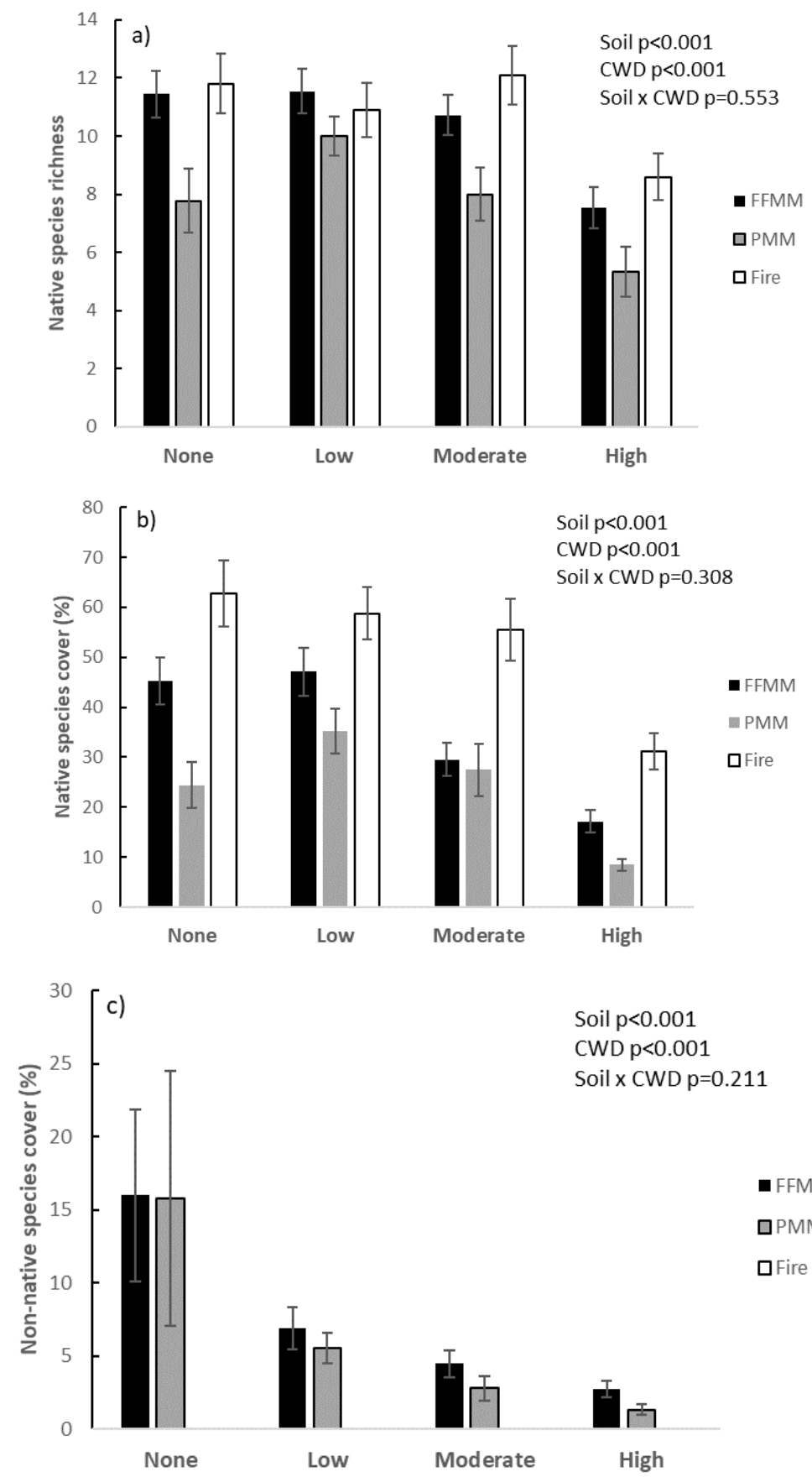

Figure 2. (a-c): Native species richness (a), native species cover (b), and non-native species cover (c) by soil type and CWD level. Values have a mean and standard error.

Average basal stem diameter of aspen trees was significantly greater on Fire than on reclaimed sites (Fire $>$ PMM $=$ FFMM, $p<0.001$ ) while High CWD plots had significantly smaller aspen diameters than No CWD plots. All other CWD were similar ( $p=0.023$, Figure $3 b)$. White spruce basal diameter on the reclaimed sites was similar between PMM and FFMM (average $=7.2 \mathrm{~mm}$ ) and no CWD plots had significantly greater spruce basal diameter than both the moderate and high CWD plots (see Figure 3c). 

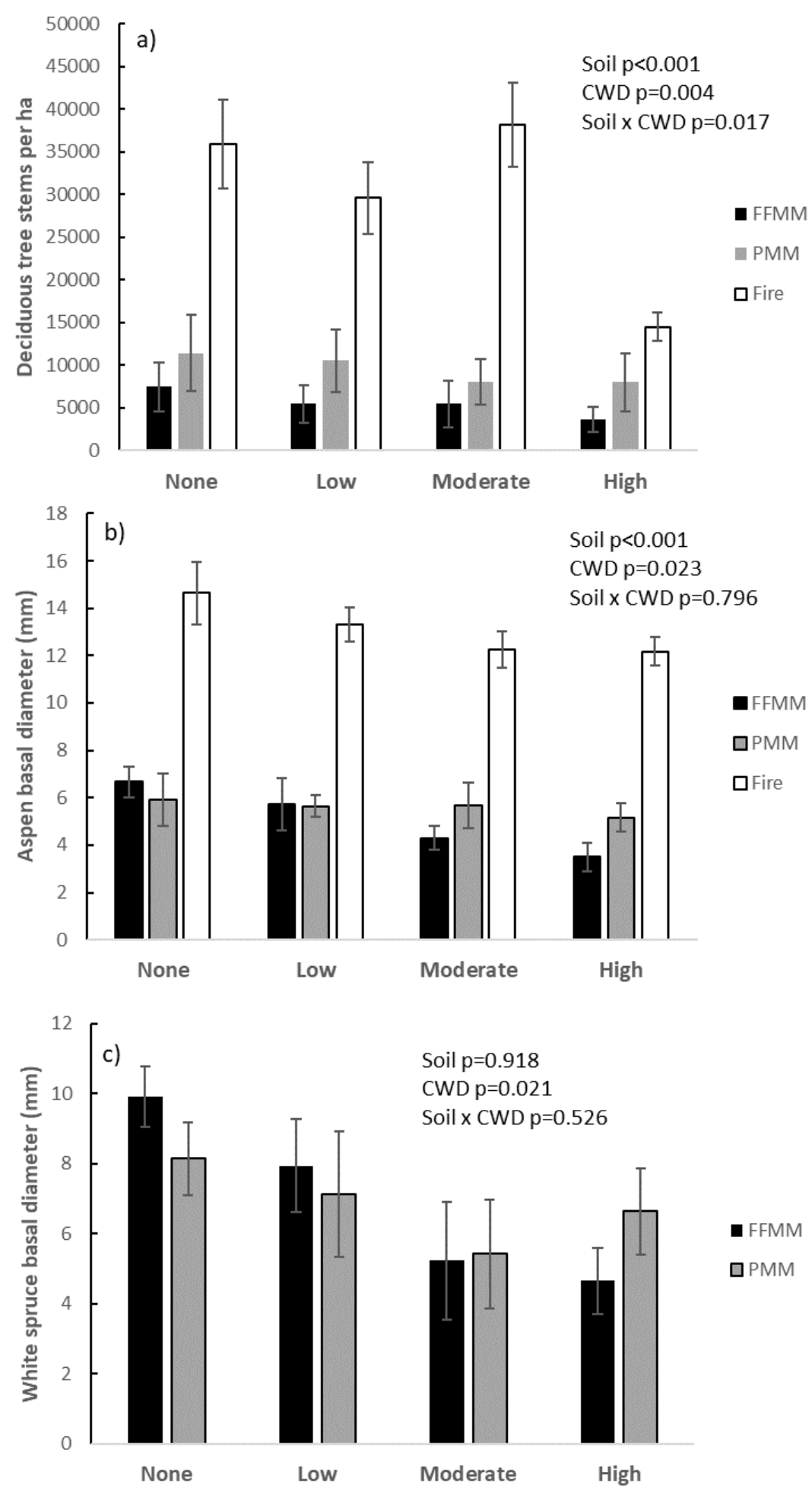

Figure 3. $(\mathbf{a}-\mathbf{c})$ : natural deciduous tree regeneration density (a), average aspen basal diameter (b), and white spruce basal diameter (c). Values have a mean and standard error.

The total inorganic $\mathrm{N}\left(\mathrm{NO}_{3}{ }^{-}+\mathrm{NH}_{4}{ }^{+}\right)$supply rate was significantly different among soil types $(p<0.001)$ but did not differ among CWD levels $(p=0.516)$ (see Figure $4 \mathrm{a})$. This same pattern of significant differences among soil types ( $p<0.001$ for all) but not among CWD levels $(p>0.144$ for all), also applies to $\mathrm{NO}_{3}{ }^{-}, \mathrm{NH}_{4}{ }^{+}, \mathrm{P}, \mathrm{K}, \mathrm{Ca}$, and $\mathrm{Mg}$ (see Table 1 ). 

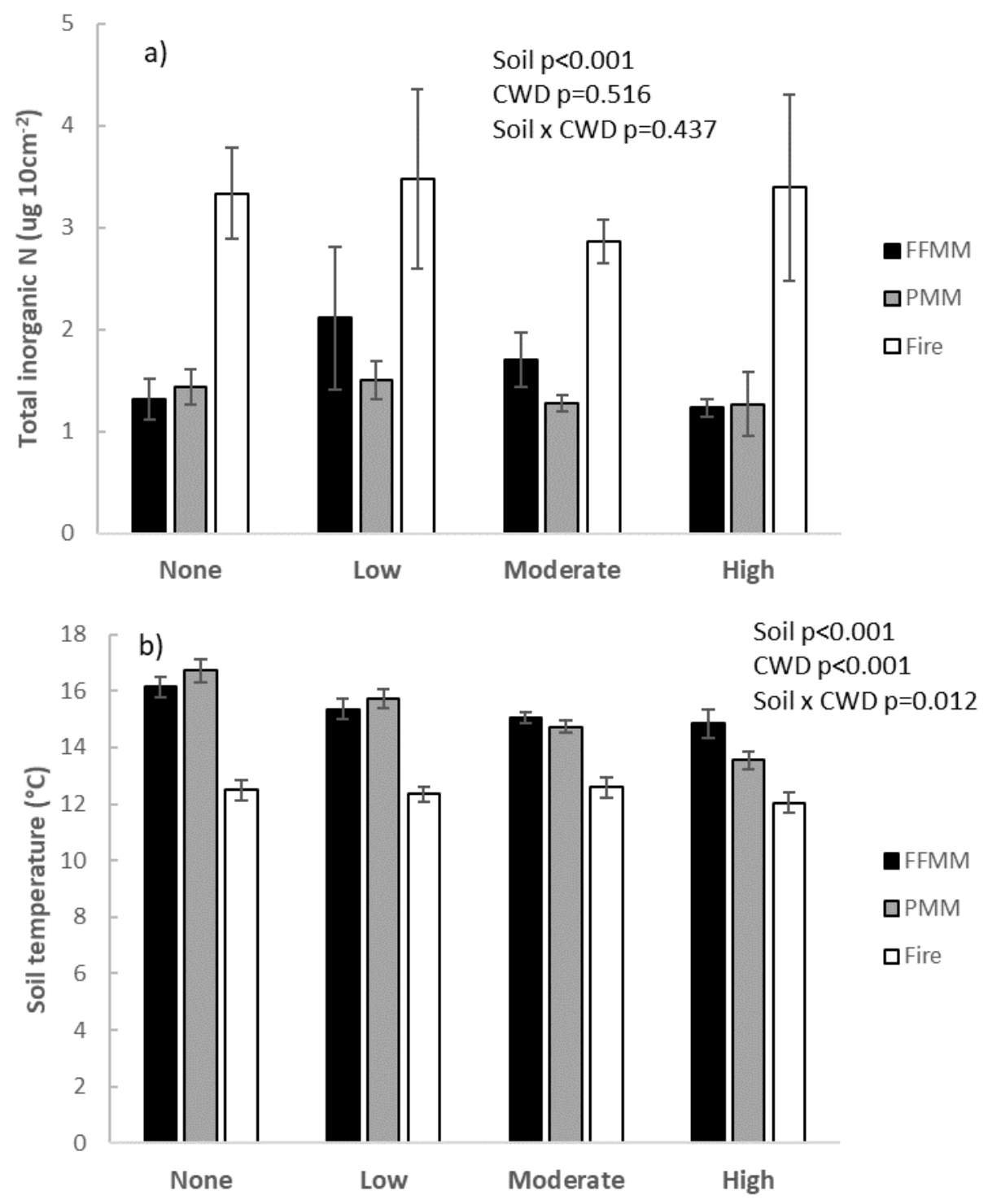

Figure 4. (a,b): soil total inorganic nitrogen $\left(\mathrm{NO}_{3}{ }^{-}+\mathrm{NH}_{4}{ }^{+}\right)$supply rate over a 55 day burial (a) and soil temperature averaged from three readings throughout the growing season (b) by soil type and CWD cover levels. Values have a mean and standard error.

Soil moisture (volumetric water content) varied over time during the growing season $(p<0.001)$ and was significantly different among all soil types $(p<0.001, \mathrm{PMM}>\mathrm{FFMM}>$ Fire $)$ but there was no significant impact from the CWD levels $(p=0.087)$. Soil temperature also varied over the course of the growing season $(p<0.001)$ and was significantly different among soil types $(p<0.001)$ with the main difference between the Fire site and the reclaimed sites as FFMM $=$ PMM $(p=0.629)$. CWD also impacted soil temperature $(p<0.001)$ with the temperature decreasing when CWD coverage increased on PMM and FFMM but there was no change in the soil temperature with CWD on Fire sites (soil $\times$ CWD interaction $p=0.012$, Figure $4 \mathrm{~b})$. Soil $\mathrm{pH}$ was significantly different among soil types $(p<0.001$, Table 1) but did not differ due to CWD levels $(p=0.240)$.

\section{Discussion}

Overall, there were many significant soil and plant community differences due to soil type but fewer differences due to CWD. This is a common finding with CWD studies that have underlying soil properties overshadowing the effects of CWD in both natural and reclaimed forests [2,5]. We did, 
however, find some significant differences due to CWD applications and these responses varied by CWD levels especially in the plant community including both native and non-native species. Native plant diversity maintained its overall species richness until High CWD levels $>75 \%$, which indicated that increases in good quality microsites for native plant establishment due to the CWD may have offset reduced growing space because of increasing CWD at all except for high CWD levels. Another study in the oil sands also found that CWD increased microsites and vegetation coverage but they did not look at differing levels of CWD coverage [2]. In addition, non-native species were reduced with Low CWD of $1 \%-30 \%$ coverage, which indicates that even small amounts of CWD can have an immediate positive impact on the plant community. Non-native plants on No CWD plots were likely more abundant there due to bare ground providing microsites for germination, lack of competition (particularly in PMM), and elevated soil temperature which would favor these ruderal type non-native weed species with short life cycles $[20,21]$. These favorable conditions are reduced with CWD application, which likely leads to a subsequent reduction in non-native species.

Trembling aspen establishment on the reclaimed sites was not impacted by CWD coverage but it did decrease under high CWD levels in the Fire sites. This difference in aspen establishment between reclaimed and natural fire origin stands likely reflects the difference in regeneration mechanisms. In the natural Fire sites, aspen regeneration is from root suckers [22] while on the reclaimed PMM and FFMM sites regeneration is from natural seedling establishment [19]. The aspen seed is tiny and well dispersed but requires exacting seedbed conditions and a constant supply of water to germinate and establish $[23,24]$. It appears that aspen seeds are able to find the appropriate seedbeds on the reclaimed sites at all CWD levels given that there is no difference in seedling density among CWD levels. The CWD may have also trapped seeds or improved microsite conditions by increasing surface roughness [15] that aided in the aspen seedling establishment. In contrast, at high CWD levels, aspen suckers in the Fire sites may have simply been limited in the area that it was physically possible to occupy. Note that aspen seedlings and sucker densities were similar at high CWD plots on all soil types and still high (5-10,000 stems per hectare) relative to normal planting densities of approximately 1600 stems per hectare.

Aspen productivity also varied by soil type with greater average basal area in the Fire sites compared to the reclamation PMM and FFMM sites. This was likely a result of the sucker origin stems on the Fire site, which have an early growth advantage by establishing from the existing root system. This allows them to prioritize aboveground growth [22]. Seedling origin aspen, on the other hand, must establish their own root system and, therefore, show reduced early aboveground growth [25]. Increasing CWD did decrease growth on the Fire site, but not the reclamation sites. Spruce basal diameter was similar between reclamation soil types and was reduced with high CWD due to the reduced soil temperature in these plots. Low soil temperature is a known limiting factor in these relatively cold boreal forest soils [26]. However, the fact that soil temperatures were at their lowest in the fire origin stands while aspen basal diameters were at their highest levels, indicates that other factors are likely controlling tree productivity at least for aspen. Similar to our findings, other studies have also found that CWD plays a secondary role after soil properties in determining tree productivity [27].

We found few differences in soil properties that were attributable to CWD, which differs from other reclamation studies examining CWD. For example, we found no differences in total inorganic $\mathrm{N}$ supply rates while a lab-based incubation study that included both PMM and FFMM but only a single level of CWD extract found that CWD decreases $\mathrm{N}$ availability due to reduced $\mathrm{N}$ mineralization and increased $\mathrm{N}$ immobilization [13]. The difference in results may have been the sub-optimal field conditions in our study. This includes soil moisture and temperature such that these same processes of mineralization and immobilization may take much longer to occur in the field than in a controlled incubation study. Also, the use of CWD extract in the incubation study rather than CWD fragments on the soil surface as in our field study may have altered nutrient cycling processes. Other studies have also shown lower inorganic $\mathrm{N}$ under CWD $[2,5]$ measured using standard extraction procedures in 
field studies. Our integrative measure of soil nutrient supply using ionic membranes depends on water moving through soil to allow nutrients to absorb to the membrane. Therefore, perhaps in this drier growing season with reduced water movement through the soil, the differences in nutrient supply rates were too subtle to detect [28]. Other soil properties such as microbial communities or enzymes [6] may have been more responsive to the CWD levels in our study but these were not the focus of our study. The relatively undecomposed CWD found in both the reclamation sites and the Fire site may have also contributed to the lack of nutrient differences among CWD treatments. Later in succession, as this material decomposes, there may be larger differences in soil nutrients due to mineralization and immobilization associated with the CWD [27].

Given the large differences in properties between FFMM and PMM reclamation soil, we expected to see more differences in the response to CWD on these soils, i.e., more soil $\times$ CWD interactions. Overall, the response of the plant community and soil properties was broadly similar to CWD applications for all soils. For example, given the higher potential plant coverage on FFMM and its greater similarity to natural forests [16], CWD could have reduced native plant diversity relatively more on FFMM than on PMM, but this was not the case. The underlying properties of the reclamation soil were clearly the major determining factor for the plant community and soil properties with only slight modifications due to CWD at high levels. Similarly, the response due to CWD between fire origin and reclaimed sites was expected to differ substantially due to the type of CWD found on the sites but only deciduous tree regeneration and soil temperature showed this through a significant soil $\times$ CWD interaction. As noted, the fire site was mainly aspen CWD with much of it still standing post-fire and in whole log form on the ground while the reclaimed site CWD was mainly coniferous and in smaller fragments. Similar differences were observed in CWD between burned and harvested areas with most CWD in harvested areas containing small pieces/fragments of wood [29], which are similar to our reclaimed sites. Charring of CWD and the production of black carbon in the midst of fires may also impact the germination of native plants [30], but the response tends to be variable by species. Therefore, quantifying the CWD profile [31] including the species, size, decay class, charring, and more than total volume may allow more subtle differences to be detected.

In the long lifespan of a boreal forest, six years post-treatment is relatively short term. However, it is still longer than many other reclamation studies, which tend to focus on the immediate impact of treatment. Many of the noted ecosystem services provided by CWD such as carbon storage, wildlife habitat, and nutrient retention $[8,10,11]$ may not occur until much later in the life of the forest stand and these should be followed up on throughout the lifespan of the reclaimed forest.

\section{Operational Implications}

Care should be taken when attempting to extrapolate the findings from this study to other reclamation sites or conditions given that this study was for a single type of CWD application, albeit at different coverage levels. The impact of other species, sizes, and decay classes of CWD on different reclamation soils are not known and should be studied. However, we looked at different levels of CWD application areas on three different soil types and found some general trends. Overall, it appears that CWD applications have some significant and immediate benefits for the understory plant community including maintaining native species and controlling non-native species and no negative impacts on tree establishment or growth until high levels of CWD. Operationally, we recommend a CWD application of up to 30\% coverage on both FFMM and PMM reclamation soils but with the caveat that CWD is not a "magic bullet" that will make a poorly constructed reclamation soil or site satisfactory.

Author Contributions: B.D.P. and S.D.G. conceived and designed the experiments. S.D.G. performed the experiments. B.D.P. analyzed the data. B.D.P. wrote the paper.

Acknowledgments: We thank Jim Weber, Kyle Stratechuk, and Jennifer Buss for help in the field and laboratory. Funding was provided from Canadian Natural Resources Limited. 
Conflicts of Interest: The authors declare no conflict of interest. The funding sponsors had no role in the design of the study, in the collection, analyses, or interpretation of the data, in the writing of the manuscript, or in the decision to publish the results.

\section{References}

1. Haskell, D.E.; Flaspohler, D.J.; Webster, C.R.; Meyer, M.W. Variation in soil temperature, moisture, and plant growth with the addition of downed woody material on lakeshore restoration sites. Restor. Ecol. 2012, 20, 113-121. [CrossRef]

2. Brown, R.L.; Naeth, M.A. Woody debris amendment enhances reclamation after oil sands mining in Alberta, Canada. Restor. Ecol. 2014, 22, 40-48. [CrossRef]

3. Cirelli, D.; Vinge, T.; Lieffers, V.J. Assisted lodgepole pine regeneration on reclamation sites using logging slash as both a mulch and natural seed source. Can. J. For. Res. 2016, 46, 1132-1137. [CrossRef]

4. Laiho, R.; Prescott, C.E. The contribution of coarse woody debris to carbon, nitrogen, and phosphorus cycles in three Rocky Mountain coniferous forests. Can. J. For. Res. 1999, 29, 1592-1603. [CrossRef]

5. Kim, S.; Li, G.; Han, S.H.; Chang, H.; Kim, H.-J.; Son, Y. Differential effects of coarse woody debris on microbial and soil properties in Pinus densiflora Sieb. et Zucc. forests. Forests 2017, 8, 292. [CrossRef]

6. Kwak, J.H.; Chang, S.X.; Naeth, M.A.; Schaaf, W. Coarse woody debris increases microbial community functional diversity but not enzyme activity in reclaimed oil sands soils. PLoS ONE 2015, 10, e0143857. [CrossRef] [PubMed]

7. Hafner, S.D.; Groffman, P.M. Soil nitrogen cycling under litter and coarse woody debris in a mixed forest in New York State. Soil Biol. Biochem. 2005, 37, 2159-2162. [CrossRef]

8. Gough, C.M.; Vogel, C.S.; Kazanski, C.; Nagel, L.; Flower, C.E.; Curtis, P.S. Coarse woody debris and the carbon balance of a north temperate forest. For. Ecol. Manag. 2007, 244, 60-67. [CrossRef]

9. Kwak, J.H.; Chang, S.X.; Naeth, M.A.; Schaaf, W. Coarse woody debris effects on greenhouse gas emission rates depend on cover soil type in oil sands reclamation. Appl. Soil Ecol. 2016, 10, 124-134. [CrossRef]

10. Siitonen, J. Forest management, coarse woody debris and saproxylic organisms: Fennoscandian boreal forests as an example. Ecol. Bull. 2001, 49, 11-41.

11. Riffell, S.; Verschuyl, J.; Miller, D.; Wingley, T.B. Biofuel harvests, coarse woody debris, and biodiversity-A meta-analysis. For. Ecol. Manag. 2011, 261, 878-887. [CrossRef]

12. Audet, P.; Pinno, B.D.; Thiffault, E. Reclamation of boreal forest after oil sands mining: Anticipating novel challenges in novel environments. Can. J. For. Res. 2015, 45, 363-370. [CrossRef]

13. Kwak, J.H.; Chang, S.X.; Naeth, M.A.; Schaaf, W. Coarse woody debris extract decreases nitrogen availability in two reclaimed soils in Canada. Ecol. Eng. 2015, 84, 13-21. [CrossRef]

14. Beckingham, J.D.; Archibald, J.H. Field Guide to Ecosites of Northern Alberta; Canadian Forest Service, Northern Forestry Centre: Edmonton, AB, Canada, 1996.

15. Pinno, B.D.; Errington, R.C. Maximizing natural trembling aspen seedling establishment on a reclaimed boreal oil sands site. Ecol. Restor. 2015, 33, 43-50. [CrossRef]

16. Errington, R.C.; Pinno, B.D. Early successional plant community dynamics on a reclaimed oil sands mine in comparison with natural boreal forest communities. Écoscience 2016, 22, 133-144. [CrossRef]

17. Mackenzie, D.D.; Naeth, M.A. The role of the forest soil propagule bank in assisted natural recovery after oil sands mining. Restor. Ecol. 2010, 18, 418-427. [CrossRef]

18. Howell, D.M.; Das Gupta, S.; Pinno, B.D.; MacKenzie, M.D. Reclaimed soils, fertilizer, and bioavailable nutrients: Determining similarity with natural benchmarks over time. Can. J. Soil Sci. 2017, 97, 149-158. [CrossRef]

19. Stefani, F.; Isabel, N.; Morency, M.-J.; Lamothe, M.; Nadeau, S.; Lachance, D.; Li, E.H.Y.; Greer, C.; Yergeau, E.; Pinno, B.D.; et al. The impact of reconstructed soils following oil sands exploitation on aspen and its associated belowground biome. Sci. Rep. 2018, 8, 2761. [CrossRef] [PubMed]

20. Zollinger, R.K.; Kells, J.J. Effect of soil pH, soil water, light intensity, and temperature on perennial sowthistle (Sonchus arvensis L.). Weed Sci. 1991, 39, 376-384.

21. Erfmeier, A.; Hantsch, L.; Bruelheide, H. The role of propagule pressure, genetic diversity and microsite availability for Senecio vernalis invasion. PLoS ONE 2013, 8, e57029. [CrossRef] [PubMed] 
22. Frey, B.R.; Lieffers, V.J.; Landhäusser, S.M.; Comeau, P.G.; Greenway, K.J. An analysis of sucker regeneration of trembling aspen. Can. J. For. Res. 2003, 33, 1169-1179. [CrossRef]

23. Barnes, B.V. The clonal growth habit of American aspens. Ecology 1966, 47, 439-447. [CrossRef]

24. McDonough, W.T. Quaking Aspen-Seed Germination and Early Seedling Growth; Research paper INT-234; USDA Forest Service: Washington, DC, USA, 1979.

25. Martens, L.A.; Landhäusser, S.M.; Lieffers, V.J. First-year growth response of cold-stored, nursery-grown aspen planting stock. New For. 2007, 33, 281-295. [CrossRef]

26. Grossnickle, S.C.; Blake, T.J. Acclimation of cold-stored jack pine and white spruce seedlings: Effect of soil temperature on water relation patterns. Can. J. For. Res. 1985, 15, 544-550. [CrossRef]

27. Brais, S.; Sadi, F.; Bergeron, Y.; Grenier, Y. Coarse woody debris dynamics in a post-fire jack pine chronosequence and its relation with site productivity. For. Ecol. Manag. 2005, 220, 216-226. [CrossRef]

28. Johnson, D.W.; Verburg, P.S.J.; Arnone, J.A. Soil extraction, ion exchange resin, and ion exchange membrane measures of soil mineral nitrogen during incubation of a tallgrass prairie soil. Soil Sci. Soc. Am. J. 2005, 69, 260-265. [CrossRef]

29. Pedlar, J.H.; Pearce, J.L.; Venier, L.A.; McKenney, D.W. Coarse woody debris in relation to disturbance and forest type in boreal Canada. For. Ecol. Manag. 2002, 158, 189-194. [CrossRef]

30. Reyes, O.; Kaal, J.; Aran, D.; Gago, R.; Bernal, J.; Garcia-Duro, J.; Basanta, M. the effects of ash and black carbon (biochar) on germination of different tree species. Fire Ecol. 2015, 11, 119-133. [CrossRef]

31. Stokland, J.N. The coarse woody debris profile: An archive of recent forest history and an important biodiversity indicator. Ecol. Bull. 2001, 49, 71-83.

(C) 2018 by the authors. Licensee MDPI, Basel, Switzerland. This article is an open access article distributed under the terms and conditions of the Creative Commons Attribution (CC BY) license (http:// creativecommons.org/licenses/by/4.0/). 